\title{
Impact of Phosphate Solubilizing Bacteria and Inorganic Fertilizers on Yield Attributes of Tomato
}

\author{
Zahoor Ahmad Baba ${ }^{1}$, Sheikh Tahir ${ }^{2}$, Fozia Shafiq Wani ${ }^{3 *}$ and Basharat Hamid ${ }^{1}$ \\ ${ }^{1}$ Biofertilizer Research Laboratory, Division of Basic Science and Humanities, Wadura, \\ ${ }^{2}$ Division of Agronomy, Sher-e-Kashmir University of Agricultural Sciences and Technology of \\ Kashmir, FOA Sopore-193 201, India \\ ${ }^{3}$ Division of Soil Science, Sher-e-Kashmir University of Agricultural Sciences and Technology \\ of Kashmir, Shalimar, Srinagar -191121, Jammu \& Kashmir (India) \\ *Corresponding author
}

Keywords

Growth, Phosphorus, PSB, Tomato, Yield.

Article Info

Accepted: 15 May 2017 Available Online: 10 June 2017

\section{A B S T R A C T}

A field experiment was carried out at farmers' fields in village Wadura (Sopore) of district Baramulla J\&K during kharif 2013 and 2014 to assess the impact of phosphate solubilizing bacterial strain and inorganic fertilizers on growth and yield of Tomato cv. 'SHALIMAR-1'. The treatments comprised of 2 levels of biofertilizers (control, PSB) in combination with 5 levels of inorganic fertilizers $[0,25,75,50$ and $100 \%$ recommended dose of fertilizers (RDF) $\mathrm{N}$ and $\mathrm{K}]$. The experiment was laid out in a randomized complete block design with each treatment replicated three times. Maximum plant height $(164.24 \mathrm{~cm})$, fruit yield $\left(1.429 \mathrm{Kg} \mathrm{plant}^{-1}\right)$, No. of Branches $\left(7.85\right.$ plant $\left.^{-1}\right)$ and Phosphorus (\%) in fruit $(0.48 \%)$ were recorded in treatment (PS6) $+75 \%$ NK. The use of PSB in combination with different $\mathrm{N}$ and $\mathrm{K}$ levels increased the phosphorus content in fruit over control. Maximum Phosphorus content $(\%)$ in fruit $(0.48 \%)$ was observed in treatment combination of (PS6) $+75 \%$ NK.

\section{Introduction}

Tomato (Lycopersicon esculentum) is an important annual vegetable crop grown throughout the world and ranks second in importance after potato. It belongs to the genus Lycopersicon under Solanaceae family. Tomato is a herbaceous sprawling plant growing to 1-3 $\mathrm{m}$ in height with weak woody stem. The flowers are yellow in colour and the fruits of cultivated varieties vary in size from cherry tomatoes, about $1-2 \mathrm{~cm}$ in size to beefsteak tomatoes, about $10 \mathrm{~cm}$ or more in diameter. Most cultivars produce red fruits when ripe. The tomato is believed to have been originated in Central Africa and South America (Vavilov, 1951). In India it is an introduced crop and in being grown on an area of 882.03 hectare with an annual production of 18735.91 metric tonnes (Indian horticulture data base, 2014). In Jammu and Kashmir states, tomato is grown on an area of 1.7000 ha with an annual production of 37000 metric tonnes. Tomato is one of the most important "protective foods" because of its special nutritive value. It is one of the 
important vegetable crop which contain some important minerals, vitamins. Lycopene, one of nature's most powerful antioxidants, is present in tomatoes. Proper plant growth and its fruits are necessary. This can be achieved to a great extent by the use of optimum levels of fertilizers. The essential elements especially the major nutrients (NPK) are considered the most important among nutrients and factors limiting growth and yield of plant, since plant growth are negatively affected by their deficiency. For enhancing the yield and quality application of adequate quantities of plant nutrients is a prerequisite which can be met both from organic as well as inorganic sources. Inadequate or imbalanced nutrient supply is one of the major factor responsible for low production. Substitution of high analysis fertilizers like urea and diammonium phosphate for increasing crop productivity or inadequate use of organic manures have rendered Indian soils deficient in macro and micro nutrients. With rapid increase in population, the demand for the crop has significantly increased, leading to extensive use of chemical fertilisers for supply of plant nutrients without any consideration for soil health, which is a critical factor for realising sustainable yield of any vegetable crop. Besides, this the residual effects of chemical fertilizers on environment, underground water, soil microflora, vegetable and vegetable products is a matter of concern, as some of the residues like nitrates enter the human body and are carcinogenic. Thus, there is an urgent need to utilise other sources of plant nutrients for sustainable and safe tomato production. The answer lies in the use of organic manurers which have a potential to provide primary, secondary and micronutrients besides building a strong organic matter base resulting in improvement of soil structure and sustainable vegetable production devoid of most of the harmful residues. But organic sources of plant nutrients supply nutrients in slow manner and thus it is essential to use both organic and inorganic plant nutrients in integrated form which has proved superior to individual sources with respect to growth, yield and quality in different vegetable crops. Phosphorus is one of the most important mineral nutrients for plant growth and development. It is second only to nitrogen, limiting the growth of crops. Plants acquire $\mathrm{P}$ from soil. However, most of the soil phosphorus, approximately 95-99\%, is present in the form of insoluble phosphates (Abou El-Yazeid et al., 2007).Compared to other essential macronutrients (with exception of nitrogen), $\mathrm{P}$ is one of the less-abundant $(0.1 \%$ of total) elements in the lithosphere (Jones and Oburger, 2011), thus often regarded as a limiting nutrient in agricultural soils. Upon application as inorganic phosphorus rapidly transformed into less available forms by forming a complex with $\mathrm{Al}$ or $\mathrm{Fe}$ in acid soils or with $\mathrm{Ca}$ in calcareous soils (Toro, 2007) thus becomes unavailable to plants. Frequent application of chemical fertilizers, on the other hand, is recognized to be a costly affair and environmentally undesirable too. Microorganisms which are capable of solubilizing insoluble phosphate, also called phosphate solubilizing microorganisms (PSMs). They offer an ecologically acceptable means for converting insoluble phosphate to soluble forms by acidification, chelation and exchange reaction. Several strains of bacteria (Pseudomonas, Bacillus, Rhizobium, Enterobacter etc.) and fungi (Aspergillus and Penicillium) have been recognized as powerful phosphate solubilizers (Whitelaw, 2000; Peela et al., 2013). PSB not only provide sustained $\mathrm{P}$ supply for the growth of plants (Walpola and Yoon, 2012; Hussain et al., 2013) but also stimulate the efficiency of nitrogen fixation and accelerate the accessibility of other trace elements by synthesizing important growth promoting substances like siderophores, antibiotics, etc. 
(Kumar et al., 2012), produce plant hormones such as auxins (Egamberdiyeva, 2005), cytokinins (Gracia de Salamone et al., 2001), and gibberellins (Gutierrez- Manero et al., 2001); and improve crop productivity (Abbas et al., 2013) by solubilizing insoluble phosphorus and providing protection to plants against soil borne pathogens.

\section{Materials and Methods}

A field experiment was carried out at farmers' fields in village wadura (Sopore) of district Baramulla J\&K during kharif 2013 and 2014 to study the effect of phosphate solubilizing bacterial strain and inorganic fertilizers on growth and yield of tomato. Four week old seedlings of tomato were transplanted on ridges in the field toward the end of February with a spacing of $60 \mathrm{~cm} \times 45 \mathrm{~cm}$. The experimental soil was silty clay loam and neutral in reaction with $\mathrm{pH} 7.6$, EC $0.14 \mathrm{dS}$ $\mathrm{m}^{-1}$, medium in available $\mathrm{N}\left(272 \mathrm{~kg} \mathrm{ha}^{-1}\right)$, available $\mathrm{P}\left(14 \mathrm{~kg} \mathrm{ha}^{-1}\right)$ and available $\mathrm{K}(218$ $\left.\mathrm{kg} \mathrm{ha}^{-1}\right)$. The treatments comprised of 2 levels of biofertilizers (control, PSB) in combination with 5 levels of inorganic fertilizers $[0,25$, 75,50 and $100 \%$ recommended dose of fertilizers (RDF) $\mathrm{N}$ and $\mathrm{K}$ ] laid out in a randomized complete block design with each treatment replicated three times. No Phosphorus was applied, $\mathrm{N}$ and $\mathrm{K}$ was applied as per treatments in form of urea and muriate of potash. Tomato variety 'SHALIMAR -1' was used. Roots of tomato seedlings were inoculated as per standard methods with the inoculant of PSB culture @ 1litre per acre of seedling. After inoculation, the seedlings were sown at a spacing of $60 \times 45 \mathrm{~cm}$ in the last week of May and harvested in the $2^{\text {nd }}$ week of September. All the cultural operations were followed as per the package of practices. Plant height was measured at harvesting from the base of plant to the base of fully opened top leaf with the help of a scale and number of branches was also counted. The fruit yield was recorded at harvest. The fruit samples collected from tomato plant at harvest time were oven-dried, processed and digested with diacid (nitric acid and perchloric acid in 3:1 ratio) for estimation of phosphorus by Systronics UV-VIS Spectrophotometer 108 (Olsen et al., 1954).Mean of the data was taken of both the years and the data was subjected to the analysis of variance as per the standard method given by Panse and Sukhatme (1967). The data was analyzed by using ' $R$ ' software and significance of treatment effects tested by "F" test.

\section{Results and Discussion}

\section{Tomato yield}

Fruit yield recorded a significant increase due to application of PSB in combination with various inorganic levels of fertilizer over control (Table 1). The maximum fruit yield $\left(1.429 \mathrm{~kg} \mathrm{plant}^{-1}\right)$ was recorded with the application of Phosphate solubilizing bacteria (PS6) $+75 \%$ NK which was statistically at par with 100\% NPK (Recommended).Enhanced availability of $\mathrm{P}$ and its active involvement in shoot and root growth led to better plant growth, which later translated into higher yield attributes and resultant yield of tomato. The increase in fruit yield of tomato with inoculation of $\mathrm{P}$ solubilizing microorganisms may be due to increase in $P$ availability through solubilization of insoluble inorganic phosphate by organic acid, decomposition of phosphate-rich organic compounds and production of plant growth promoting substances (Gaur and Sunita, 1999). Microorganisms enhance the $\mathrm{P}$ availability to plants by mineralizing organic $\mathrm{P}$ in soil and by solubilizing precipitated phosphates (Chen et al., 2006).

These bacteria in the presence of labile carbon serve as a sink for $\mathrm{P}$ by rapidly immobilizing it even in low $\mathrm{P}$ soils (Bünemann et al., 
2004). Subsequently, PSB become a source of $\mathrm{P}$ to plants upon its release from their cells. Similar results were reported in tomato (ElTantawy and Mohamed, 2009; Poonia and Dhaka, 2012)

\section{Plant height and number of branches}

Plant height showed a significant increase due to various treatments as compared to control with maximum height $(164.24 \mathrm{~cm})$ and number of branches (7.85 plant $\left.^{-1}\right)$ in (PS6) $+75 \%$ NK treatment which was at par with $100 \%$ NPK (Table 1). This increase may be attributed to the auxin production by PSB and increased supply of phosphorus by PSB and VAM (Fankem et al., 2008). Also the increase in growth characters might be due to stimulative effect of PSB on P solubilization leading to higher $\mathrm{P}$ availability and uptake by plants (Sharma et al., 2007 and Turan et al., 2007). Higher microbial activity in rhizosphere expressed as activity of hydrogenase, phosphates and nitrogenase enzymes was also reported (El- Tantawy and Mohamed, 2009). These results are in conformity with the findings of (Poonia and Dhaka, 2012).

Table.1 Effect of phosphate solubilizing bacteria and inorganic fertilizers on yield attributes of tomato (2013-14)

\begin{tabular}{|l|c|c|c|c|}
\hline TREATMENTS & $\begin{array}{l}\text { Plant Height } \\
(\mathrm{cm}) .\end{array}$ & $\begin{array}{l}\text { No. of } \\
\text { Branches }_{\text {plant }^{-1}}\end{array}$ & $\begin{array}{l}\text { Fruit yield } \\
\left.\text { Kg plant }^{-1}\right)\end{array}$ & $\begin{array}{l}\text { Phosphorus (\%) } \\
\text { in fruit }\end{array}$ \\
\hline $\begin{array}{l}\mathrm{T}_{0}=\text { Control } \\
\text { (No bio-fertilizer or NPK) }\end{array}$ & 102.79 & 5.74 & 0.837 & 0.26 \\
\hline $\begin{array}{l}\mathrm{T}_{1}=\text { Phosphate solubilizing } \\
\text { bacteria (PS6)+25\% NK }\end{array}$ & 130.27 & 6.20 & 1.121 & 0.35 \\
\hline $\begin{array}{l}\mathrm{T}_{2}=\text { Phosphate solubilizing } \\
\text { bacteria (PS6)+50\% NK }\end{array}$ & 142.19 & 6.58 & 1.228 & 0.39 \\
\hline $\begin{array}{l}\mathrm{T}_{3}=\text { Phosphate solubilizing } \\
\text { bacteria (PS6)+75\% NK }\end{array}$ & 164.24 & 7.85 & 1.429 & 0.48 \\
\hline $\begin{array}{l}\mathrm{T}_{4}=\text { Phosphate solubilizing } \\
\text { bacteria (PS5)+25\% NK }\end{array}$ & 129.37 & 6.18 & 1.098 & 0.32 \\
\hline $\begin{array}{l}\mathrm{T}_{5}=\text { Phosphate solubilizing } \\
\text { bacteria (PS5)+50\% NK }\end{array}$ & 141.28 & 6.54 & 1.201 & 0.37 \\
\hline $\begin{array}{l}\mathrm{T}_{6}=\text { Phosphate solubilizing } \\
\text { bacteria (PS5)+75\% NK }\end{array}$ & 163.33 & 7.00 & 1.310 & 0.47 \\
\hline $\begin{array}{l}\mathrm{T}_{7}=\text { Phosphate solubilizing } \\
\text { bacteria (PS1)+25\% NK }\end{array}$ & 127.19 & 6.14 & 1.008 & 0.31 \\
\hline $\begin{array}{l}\mathrm{T}_{8}=\text { Phosphate solubilizing } \\
\text { bacteria (PS1)+50\% NK }\end{array}$ & 138.25 & 6.41 & 1.121 & 0.37 \\
\hline $\begin{array}{l}\mathrm{T}_{9}=\text { Phosphate solubilizing } \\
\text { bacteria (PS1)+75\% NK }\end{array}$ & 164.00 & 6.99 & 1.300 & 0.44 \\
\hline $\begin{array}{l}\mathrm{T}_{10}=100 \% \mathrm{NPK} \\
\text { (Recommended) }\end{array}$ & 163.00 & 6.94 & 1.298 & 0.43 \\
\hline CD & 1.7 & 0.92 & 0.83 & 0.26 \\
\hline
\end{tabular}




\section{Phosphorus (\%) in fruit}

Phosphorus content in fruit was markedly influenced by PSB in combination of with different levels of NK. There was an increase in phosphorus content in fruit due to various treatments as compared to control. The highest phosphorus content of $0.48 \%$ was recorded by the treatment (PS6) $+75 \% \mathrm{NK}$ which was at par with the treatments Phosphate solubilizing bacteria (PS5) $+75 \%$ NK, Phosphate solubilizing bacteria (PS1) $+75 \%$ NK, $100 \%$ NPK (Recommended). This might be due to their ability to solubilize/ mineralize the native phosphorus (Asco et al., 1988). PSB can solubilize the fixed phosphorus to available $\mathrm{P}$ by the secretion of various organic acids, phosphatase enzyme and growth hormones and increase the availability of phosphorus to plant in turn increasing the uptake of $\mathrm{P}$ (Yadav et al., 2011) in addition to lowering the $\mathrm{pH}$ of rhizosphere. Similar results were obtained by (Walpola and Yoon, 2013).

The present study revealed that the use of $75 \%$ NK along with PSB influenced the growth and yield of tomato as well as improved nutrient availability. The application of $75 \% \mathrm{NK}$ along with PSB appears to be suitable combination for high yield under temperate conditions of Kashmir valley.

\section{References}

Abbas, Z., Zia, M.A., Ali, S., Abbas, Z., Waheed, A., Bahadur, A., Hameed, T., Iqbal, A., Muhammad, I., Roomi, S., Zulfiqar, M. and Sultan, T. 2013. Integrated effect of plant growth promoting rhizobacteria, phosphate solubilizing bacteria and chemical fertilizers on growth of maize. International Journal of Agriculture and Crop Sciences, 6: 913-921.
Abou El-Yazeid, A., H.E. Abou-Aly, M.A. Magdy and S.A.M. Mousa, 2007. Enhancing growth, productivity and quality of squash plant using phosphate dissolving microorganisms (Biophosphor) combined with boron foliar spray. Research Journal of Agriculture and Biological Sciences, 4: $274-286$.

Asco, P.E.A., Kucey, R.M.N. and Stewart, W.B. 1988. Inorganic phosphate solubilization by two Penicillium species in solution culture and soil. Soil Biol. Biochem., 20: 459-464.

Bünemann, E. K., Bossio, D. A., Smithson, P. C., Frossard, E. and Oberson, A. 2004. Microbial community composition and substrate use in a highly weathered soil as affected by crop rotation and $\mathrm{P}$ fertilization. Soil Biol. Biochem., 36: 889-901

Chen, Y. P., Rekha, P. D., Arunshen, A. B., Lai, W. A. and Young, C. C. 2006. Phosphate solubilizing bacteria from subtropical soil and their tricalcium phosphate solubilizing abilities. Applied Soil Ecology, 34: 33-41

Egamberdiyeva. D (2005). Plant growth promoting rhizobacteria isolated from a Calcisol in a semi-arid region of Uzbekistan: Biochemical characterization and effectiveness. Journal of Plant Nutrition and Soil Science, 168: 94-99.

El-Tantawy, M.E. and Mohamed, M.A.N. 2009. Effect of Inoculation with Phosphate Solubilizing Bacteria on the Tomato Rhizosphere Colonization Process, Plant Growth and Yield under Organic and Inorganic Fertilization. Journal of Applied Sciences Research, 5: 1117-1131.

Fankem, H., Laurette, N.N., Annette, D., John, Q., Wolfgang, M., FrançoisXavier, E. and Dieudonné, N. 2008. Solubilization of inorganic phosphates 
and plant growth promotion by strains of Pseudomonas fluorescens isolated from acidic soils of Cameroon. African Journal of Microbiology Research, 2: 171-178.

Gracia de Salamone, I.E., Hynes, R.K. and Nelson, L.M. 2001. Cytokinin production by plant growth promoting rhizobacteria and selected mutants. Canadian Journal of Microbiology, 47: 404-411.

Gaur, A.C. and Sunita, G. 1999. Phosphate solubilizing microorganisms - An overview. Current Trends in Life Science, 23: 151-164.

Gutierrez-Manero FJ, Ramos-Solano B, Probanza A, Mehouachi J, Francisco RT, Manuel T (2001). The plantgrowth-promoting rhizobacteria Bacillus pumilis and Bacillus licheniformis produce high amounts of physiologically active gibberellins. Physiologia Plantarum, 111: 206-211.

Hussain, M.H., Asghar, H.N., Akhtar, M.J. and Arshad, M. 2013. Impact of phosphate solubilizing bacteria on growth and yield of maize. Soil Environment, 32: 71-78.

Jones, D.L. and Oburger, E. 2011. Solubilization of phosphorous by soil microorganisms. In: Buneman, E., Oberson, A., Frossard, E. (eds.) Phosphorous in action, Biological processes in soil phosphorous cycling. Springer Berlin Heidelberg, 100: 169198.

Kumar, A., Kumar, A., Devi, S., Patil, S., Payal, C. and Negi, S. 2012. Isolation, screening and characterization of bacteria from rhizospheric soils for different plant growth promotion (PGP) activities: An in vitro study. Recent Research in Science and Technology, 4: 1-5.

National Horticulture Board (NHB), "Indian Horticulture Database 2014".
Olsen, S.R., Cole, C.V., Watanabe, F.S. and Dean, L.A., 1954. Estimation of Available Phosphorus in Soils by Extraction with Sodium Bicarboanate. Circular No.939. US Department of Agriculture, Washington, USA.

Panse, V.G. and Sukhatme, P.V. 1967. Statistical Methods for Agricultural Workers (2nd edn.). Indian Council of Agricultural Research, New Delhi, India.

Peela, S., Kadiri, D.D., Gorle, N. and Peetala, K.V.R. 2013. Isolation, screening and identification of phosphate solubilizing bacteria from different regions of Visakhapatnam and Araku valley. International Journal of Advanced Biotechnology and Research, 4: 518526.

Poonia, M.K. and Dhaka, B.L. 2012.Effect of phosphorus solublizing bacteria (PSB) on growth and yield in tomato. Journal of Horticultural Science, 1: 104-107

Sharma, K., Dak, G., Agrawal, A., Bhatnagar, M. and Sharma, R. 2007. Effect of phosphate solubilizing bacteria on the germination of Cicer arietinum seeds and seedling growth. Journal of Herbal Medicine and Toxicology, 1: 61-63

Turan, M. Ataoglu, N. and Sahin, F. 2007. Effect of Bacillus FS-3 on growth of tomato (Lycopersicon esculentum L.) plant and availability of phosphorus in soil. Plant Soil Environment, 53: 58-64

Toro, M. 2007. Phosphate solubilizing microorganisms in the rhizosphere of native plants from tropical savannas: An adaptive strategy to acid soils In: Velaquez, C., Rodriguez-Barrueco, E. (eds.) Developments in Plant and Soil Sciences. Springer, the Netherlands, 249-252.

Vavilov. 1951 by R. W. Schery, Plants for Man, Prentice Hall, Englewood Cliffs, NJ, 1972

Walpola, B.C. and Yoon, M. 2012. Isolation 
and characterization of phosphate solubilizing bacteria and their coinoculation efficiency on tomato plant growth and phosphorous uptake. African Journal of Microbiology Research, 7: 266-275.

Walpola, B.C. and Yoon, M. 2013. Phosphate solubilizing bacteria: Assessment of their effect on growth promotion and phosphorous uptake of mung bean (Vigna radiata). Chilean Journal of
Agricultural Research, 73: 275-281

Whitelaw, M.A. 2000. Growth promotion of plants inoculated with phosphate solubilizing fungi. Advances in Agronomy, 69: 99-151.

Yadav J, Yadav S and Singh S G. 2011. Plant growth promotion in wheat crop under environmental condition by PSB as biofertilizer. Research Journal of Agricultural Science, 2: 76-78.

\section{How to cite this article:}

Zahoor Ahmad Baba, Sheikh Tahir, Fozia Shafiq Wani and Basharat Hamid. 2017. Impact of Phosphate Solubilizing Bacteria and Inorganic Fertilizers on Yield Attributes of Tomato. Int.J.Curr.Microbiol.App.Sci. 6(6): 3233-3239. doi: https://doi.org/10.20546/ijcmas.2017.606.381 